\title{
A Deep-Seated Psychoanalysis of Law from the Theoretical Foundation: Bangladesh Perspectives
}

\author{
Mohi Uddin ${ }^{1 *}$, Muhammad FarhadHosen ${ }^{1}$, MD. Ridwan(Goni) ${ }^{2}$ \\ 1. Lecturer, Department of Law, International Islamic University Chittagong \\ 2. Assistant Professor, Department of Law, International Islamic University Chittagong
}

\begin{abstract}
Laws are made for the welfare of the people, to bring a balance in society, a harmony between theconflicting forces in the society and above all one of the prime objects behind the enactment of the law is to maintain law and order situation in society and a peaceful environment for the progress of the people. The law developed from various perspectives of view. Among them, the theoretical and jurisprudential aspects are very vital for the same. This research will try to define the law and its relationship with the different elements of the state. There will be a strong effort to show that the law from ancient to till today standing on its theoretical foundation.
\end{abstract}

Keywords: Law, Theories of Law, Philosophy of Law, Practice, Bangladesh, and Philosophical aspects.

\section{INTRODUCTION}

Man is the best creation of the creator Almighty Allah. Allah has created all the creation for his worship (Ibadah). Other than man, all creations have been worshiping Allah compulsorily, without any hesitation or deviation. Allah has created mankind as his representative on the earth with a view to testily then how far mankind may be able to fulfill this objective. For this reason human being has been given special features such as- i. rationality, and wisdom, ii. freedom of choice of virtue or evil, iii. dependent on each other for the fulfillment of their needs, iv. A difference for their easy identification, v. conflicting nature of the conduct, vi. loyalty to the superiors for escaping from the fear and attracting favor (Khan, M. A. A. 2010.p.1).With a view to lead, having possessed these natures, a harmonious life in the society, human beings undertake their social interaction through the different forms of social process co-operation, Competition, Accommodation, Assimilation andconflict.

However, human development, preservation and protection solely depend on the proper and balanced lawandregulationoftheseformsofsocialprocessaswithoutwhichhumanlifebecomesdangerous. Hence ,people has established state having given the authority to it to lead and regulate the social process as such people may lead their life with law, regulation and justice. No society or state can lead a peaceful and prosperous life without framing or drafting of proper laws and regulations to ensure justice.So that no one interferes with the functions of the other. Every jurist and scholars are of the opinion that law is one of the basic elements ofthestatewhosefundamentalfunctionsistoensurebalanceandabovealladministrationofJustice(Khan,M.A. A. 2010.p.1.).

Now the question: What is law?A widespread expression still haunts jurists as to accurately 'what law is'. There is a well-known proverb that- "If anyone were to state emphatically that he knew the exact answer to the question "what is law?" hewould deserve to be regarded either as a fool or as the greatest philosopher living". The worldwide dilemma about defining this term is that the process of definition is itself fundamentally arbitrary. One may use the term to comprehend 'the laws of nature'; or the laws of cricket'; or 'the laws of Morality' etc. (Halim, M. A. (2014). A good operational and convenient definition should be that 'law is a body of rules, whether officially enacted or customary, which is state or community recognizes as binding on its members or subjects' and it may also be said that 'law is a body of rules which are enforceable in a court of law'. In other words, if a norms or rules are not enforceable in the court of law, that norms or rules cannot be treated to be a law in strict sense (Halim, M. A. (2014).Man is by born different from each other but law from years to year has been developed under the hands of the powerful men to make equality among all (Ahamuduzzaman,2012). 


\section{METHODOLOGY}

This research is basically conducted by following the theoretical methods and as such it is prepared on the basis of secondary data like -research articles, Books, journals, Legal Decisions of the Apex Court, online sources etc. and no primary data is used here.

\section{OBJECTIVES OF THESTUDY}

i. To analysis the law from jurisprudentialview;

ii. To show the relationship of law with the different variables of thestate;

iii. To critically explain the theoretical foundation or basis of law for the enhancement of the legal systemin Bangladesh.

\section{CONCEPT OFLAW}

The term 'Law' has been derived from the Teutonic word 'Lag, which means 'definite'. On this basis Law can be defined as a definite rule of conduct and human relations. The concept, sources and schools of law are the subject matter of jurisprudence. The word 'Jurisprudence' derives from the Latin term 'Jurisprudentia" here "Juris" means "Law" and "Prudentia" means science or knowledge. So jurisprudence means "Knowledge of law" or "Science of law" or "Skill of law" (Ahmuduzzaman, 2012, p 17). Law is a body of rules, whether formally enacted or customary, which a state or community recognizes as binding on its members or subjects and it may also be said that law is a body of rules which are enforceable in a court of law (Halim, M. A. 2014). Again, various schools of law have also defined law from different angles. Some have defined it on the basis of its nature and some other on the basis of its sources and its effect on the society but a definition which does not cover various aspects of law is bound to be imperfect. (Ahamuduzzaman, 2012).According to the Article -152 of the Constitution of the People's Republic of Bangladesh,-"Law means any act, ordinance, order, rule, regulation, bye- law, notification or other legal instrument and any custom or usage, having the force of law inBangladesh". Law is the command of the sovereign (John Austin). Every law is a gift of God and a decision of sages (Demosthenes). Law is a general rule of external human action enforced by a sovereign political authority (Prof.Holland).Law is the king of all mortal and immortal affairs, which ought to be the chief, the ruler and the leader of the noble and the base and thus the standard of what is just and unjust, the commander to animals naturally social of what they should do, the forbidder of what they should not do (Justinian); The art or science of what is equitable and good (Ulpian); Law is the Command of the Sovereign It imposes a duty and is backed by a sanction and according to his view; the elements of law are as follows:

i. Command

ii. Duty

iii. Sanction(Austin);

Again, he also define law as the aggregate of rules set by men as politically superior, or sovereign over the men who are politically subject or subordinate.

\section{CATEGORIES OFLAW}

\section{a) Public internationalLaw}

Public international law deals with the bodies of rules which the states have established in their mutual dealings and relations. Such as - the law of war, the law of peace and the law of Neutrality are generally known as public international law. It is based on the treaties or international conventions. It may be civil in nature, such asConvention on liability for collusion on the high seas; Double taxation agreements etc. It may also be the Criminal in nature, such as Treaties on Extradition; Piracy on the high seas; Oil pollution offences etc.

\section{b)Private internationalLaw}

The law which discuss with the relationship of the citizen of one state with other is known a private international law. It is mainly civil in nature i.e. rules for determining the validity of foreign marriage, divorce and contract entered into between two foreign persons or companies etc. the private international law is concern with the three questions,namely:

i. The jurisdiction of domesticcourt;

ii. The choice oflaw;

c) PublicLaw

iii. The jurisdiction of foreigncourt.

Public law determines and regulates the organization and functioning of the state and its relationship with the citizens i.e. the Constitutional law, the Criminal law, law of taxation and administrative law etc.

\section{d) PrivateLaw}

Private law determines and governs the relations and dealings with the citizen's one with the others e.g. Law of Contract, Law of Torts, and Law of Property etc. 


\section{e) SubstantiveLaw}

Substantive law is the part of the law that creates, defines and regulates the rights, duties and powers of parties. When a particular law defines rights and crimes or any status, is called the substantive law e.g. Penal Code, 1860, The Contract, 1872, The Transfer of Property, 1882, etc. The functions of the substantive law are to define, create or confer substantive legal rights or legal status or to impose and define the nature and extent of legal duties (Halim, M. A. 2014.p.38).

\section{f) ProceduralLaw}

Procedural law is the rules that prescribe the steps for having a right or duty judicially enforced. It is also termed as adjective law. When a particular law determines the remedies or outlines the procedures of case or litigations of substantive offences or matters is called the procedural law or adjunctive law e.g. The Code of Criminal Procedure,1898, The Code of Civil Procedure,1908, the Evidence Act,1872, the Public Demand Recovery Act,1913 etc. The functions of practice and procedural law is to provide the machinery or the manner in which legal rights or status and legal duties may be enforced or recognized by a court of law or other recognized or properly constituted tribunal(Halim, M. A.2014.p.38)

\section{SOME KEY TERMS RELATING TO THE LAW ANDLEGALSYSTEMS OF BANGLADESH}

a) Act

Act means a law which is passed by the parliament.(Article -65 of the Constitution of the People's Republic of Bangladesh). But in penal law or in conventional sense Act means to do something and omission means to refrain from doing something

b) Ordinance

Ordinance means the law which is promulgate by the president when the parliament stands dissolved or is not in session. (Article -93 of the Constitution of the People's Republic of Bangladesh)

c) Order

Order means a law which is promulgated by the President when there is no constitution or theConstitution is in Process e.g. The Bangladesh Legal Practitioners and Bar Council Orders, 1972.

\section{d)Custom}

Holland observes that-'Custom is a generally observed course of conduct'. Blackstone states that -'A custom, in order to attain its legal binding force, must have been used so long that the memory of man runneth not to the contrary'.

\section{e) Usage}

Usage means the behavior of a particular society in respect of a particular matter which they observe for long time spontaneously. An ancient and popular usage becomes a custom. 'Gaya Holood' is a usage which is observed before marriage ceremony in the Indian Sub-Continent.

\section{f) Precedent}

Precedent means the judicial decisions of the Superior Court and is binding upon the subordinate Court. In Bangladesh under Article -111 of the Constitution, Judgment passed by the Appellate Division and High Court Division is precedent. The theory of binding force of precedent is firmly established in England and in Indian -Continent it was first proposed by the Dorin, a Judge of the SadarDiwaniAdalath at Calcutta in 1831.

\section{LAW AND ITS RELATIONSHIP WITH DIFFERENTVARIABLES}

\section{a) Law and State}

The relationship between the law and state is very close and intimate. The state manifests or expresses itself through law and law has its importance or sanctity because it has the sanction of the state. There are three theories with regard to the relationship between the law and state (Mahajan V.D. 2003.p.114); namely-

i. The first theory is that the state is superior to law and creator of law. Salmond writes in this regard that it is in and through the state alone that law exists'. Austin defines law as a "command of the sovereign and he himself is not bound by the same". The subject cannot have any right against the sovereign. Rules which have not been made by the state are not law and in this sequence - International law is not law at all as it is merely a positive morality. There was a reaction against the theory which was contended that law is anterior to the state and is not always made by thestate. 
ii. The second theory is that law is more important than the state and the state is bound by law as the same is anterior to the state (Mahajan V.D. 2003.p.114).Laski writes that the rule of law is clearly independent of the state and is indeed interior to state. Miler observes that law like language and spring from the society itself and one of its first works is the creation of the state. Lastly Jellinek says that although the state creates law, it is bound byit.

iii. The third theory is that the state and the law are one and the same thing. They both merely indicate the legal order. Keelson is one of the advocates of this view. According to him, the term state and law is same thing. These two terms are used because we look from two different angles. When we think in terms of rules, we call it as law. On the other hand, when we think in terms of institution created by those rules, we call it state (Mahajan V.D. 2003.p.113). Keelson's this theory is criticized by the Miller who observes that "-The identification of law with the state is like the identification of relationship between church and state or religion and state".

\section{b)Law and Politics}

Law and state seems to be involved into the 'chicken and egg' debate. It is the politics which gives rise to law in the sense that most of the social claims being between the individuals and between the society and individual come into being as a result of social interaction. This interaction between individuals or between society and individuals press for movement so that those claims are recognized as law in the society. This movement is nothing but the politics and this politics compels the government to make law in the areas for which the movement is mounted (Halim, M. A. 2014.p.33) . On other hand, it is the law made by the state mechanism and its shortcomings which gives rise to movement for necessary change and this movement or politics is nothing but the result of the law.

\section{c) Law and Rights}

Right means a claim of some interests' adverse by an individuals or group of individuals which has either moral or legal basis and which is essential for his development in the society. In a sense right is not created by law; it originates itself as an obvious result of mutual interaction between man and society. Rights are primarily divided into two categories-

\section{d)Moral rights and Legalrights}

Moral rights are those rights which have their basis on the rule of natural justice and the violation of which results in moral wrong. Legal rights are those rights which are recognized by the positive law of the country and can claim on legal basis and the violation of which results in legal wrong.

\section{e) Law andMorality}

Both the concepts of law and morality refer to rule of behavior in the society by individuals. Rule is a kind of norm and norm means the way in which we behave in the society. Rules may be categorized into two divisions; namely-

\section{f) Legal rules that's theLaw and Moral rules that's theMorality}

Legal rules are those rules which are mandatory for the individual to abide by and breach of which gives rise to legal sanction or penalty. On the other hand, moral rules are those rules the breach of which does not give rise to any sanction or penalty in law. Morality is based on religious ideas and the breach of morality gives raise to moral wrong which has nothing to do with punishing the offender. For instance; in English law committing murder is a crime and the punishment is life imprisonment in the maximum. On the other hand, adultery is not a crime thought is against morality and the direct breach of moral rules in the society. Similarly, in Bangladesh telling a lie or not giving Salam, is not an offence although is against the morality (Halim, M. A. 2014.p.35).

\section{g) Law and Custom}

Sometimes custom in the society has the effect of law. Say for example; in our society there is no law or written rule for Hindu marriage and its registration. The whole institution is based on custom of the Hindu society and when a dispute regarding Hindu marriage comes to the court for settlement, the court gives decision on the basis of available customs in the Hindu society (Halim, M. A.2014.p.40).

\section{h)Law andJustice}

The concept of justice is much wider than the concept of law. Law is sometimes treated as a means of getting justice. This is why it is said that where there are more laws, there is less justice. A law may not result in justice and when a law enacted by the parliament turns out to be an engine of oppression, it is not at all a means to justice; rather an instrument of injustice(Halim, M. A. 2014.p.40). 


\section{LAWS INBANGLADESH}

There are about 1200 laws in Bangladesh of which 366 are pre-independence laws and the rest of the laws have been made after the independence. To be remember that this statistics is constantly changing as because the parliament makes laws and sometimes repeals old laws and the number of laws so changes. (Halim, M. A. 2014.p.40)

\section{THEORETICAL FOUNDATION OFLAW}

The theories may be different on the basis of research. The contemporary law and legal system are developed on the basis of different types of theories in their respective arena. That means the theories of natural justice research is different from the theories of research of criminal justice. In the same way the theories of the research of Maritime affairs is completely different from the theories of perusing constitutional research.

\section{Theories of Natural Justice}

Natural justice is a concept of common law and it is the common law world counterpart of the American theory of "Procedural due process" (Talukder, S.M. H. 1994.p.118). Natural justice represents higher procedural principles developed by the judges which every administrative authority must follow in taking any decision adversely affecting the rights of private individual( Massey, I.P,2001,P.170).

\subsection{No man shall be Condemn Unheard}

In Latin term it is termed as -"AudiAlteramPartem" which means to hear the other party. So This theory is also called the 'Hear the other Side theory'. That means no man shall be punished unheard or both the sides of the proceeding must be heard for the best interest of the justice before passing any order ( Faruque, G. O.2005.p.206). This is the first principle of jurisprudence of civilized nation and the same also supported by the laws of men and God. A party is not to suffer in person or in purse without an opportunity of being heard and before passing an order against any person, reasonable opportunity of being heard must be given to him and this proposition includes two elements; Namely:-

\section{a) Notice}

Before any action is taken against any accused or any citizen, the affected person must be given a notice to show cause as to why the proposed action will not be taken and seek explanation from him; it is the right of the fair hearing. If any order or action is taken without following the above procedure of notice then it shall be the abuse of the process of the principle of natural justice and is void abinitio(Faruque, G. O.2005.p.207).

\section{b) Hearing}

The person concerned must be given an opportunity of being heard before any adverse action or decision is taken against him. In this regard, Ridge vs. Baldwin is called the 'Magna Carta' of the principle of natural justice. In that case, "The plaintiff, a chief constable had been prosecuted but acquitted on certain charges of conspiracy. In the course of judgment, the presiding judge against the plaintiff's character made certain observation, the watch committee dismissed the plaintiff from service, the court of appeal held that the watch committee was acting as an administrative authority and was not exercising judicial or quasi-judicial proceeding for dismissal. Reversing the decision of the court of appeal without giving a reasonable opportunity of being heard and without observing the principle of natural justice"(Faruque, G. O.2005.p.208).Every accused person has the absolute right to prove him innocent and for that reason he must be given a reasonable opportunity to defend himself personally (MahmudurRahaman Case) or through a Legal representative (Lawyer or pleader). But what are happening in the banner of self-defense or exercise of right of private defense by the member of law enforcing agencies, not reasonable andjustifiable

\subsection{No man shall be judge for his own cause}

The Latin term of the theory is the -"Nemodebetessejudex inpropriacausa". The first requirement of the natural justice is that the judge should be impartial and neutral and must be free from bias and he is supposed to indifferent to the parties to the controversy (Faruque, G. O.2005.p.202).Under this theory, a police officer cannot investigate the offence or crime committed by the member of any law enforcing agencies in Bangladesh. If do this the procedure is the total violation of this theory of Natural Justice. This is one of the major problems of investigation procedure in Bangladesh. We are still lacking a separate investigation cell in each district under the direct control and supervision of the Distract Judge of the Concern district inBangladesh. On the basis of this theory there are three types of bias, namely- 


\section{a) Pecuniary bias:}

It is well settled that a pecuniary interest in the subject matter of the litigation will disqualify any person from acting as a judge (Faruque, G.O.2005.p.202)..

\section{b)Personalbias:}

A number of circumstances may give rise to personal bias. Hence a judge may be a relative, a friend, a business associate of a party and in that occasion he may have some personal grudge, enmity, or grievance or professional rivalry against him (Faruque, G. O.2005.p.203).

\section{c) Officialbias:}

This may arise when the judge has a general interest in the subject matter of the proceeding. According to Griffith and Street, only rarely will this bias invalidate proceedings as mere general interest in the general object to be pursued would not disqualify a judge from deciding the matter (Faruque, G. O.2005.p.204).

\section{d)Likelihoodbias}

This is the new dimension of the principle of biasness in the judicial proceedings which is also called the real likelihood of bias. In this sense, Smith says that 'likelihood' bias means at least substantial possibility of bias.

\section{Theories of CriminalJustice}

\subsection{Presumption of innocencetheory}

This is the very emerging and reasonable theory for this research as it is only relevant for the criminal trial but the reality is very harsh as the application of the theory is only we found in the context or statute of Bangladesh. In all criminal cases, the presumption of law is that the accused is innocent and he stands before the court as an innocent person until and unless he is proven guilty and it is the business of the prosecution side lawyers to prove him to be guilty he (the accused) need not to do anything but stand-by and see what case has been made out against him (Kabir, L. 1970). The prosecution is bound to prove the guilt of the accused beyond reasonable doubts without seeking any help from then accused. if there be any reasonable doubts if the guilt of the accused he is entitled as of right to be acquitted from all types of allegation brought against him. In matter of doubts it is safer to acquit than to condemn. Since it is better that several guilty persons should escaped than one innocent person suffer.(Kabir ,L.1970).

This presumption of innocent theory of criminal trial is subject to certain modifications of offences and associate it with the accused, the question would be regarding the nature of the proof required to be given by the prosecution. According to this theory if it is the absolute duty of the prosecutors to find out the real scenario of the alleged occurrence, so why the sections 167, 164 and 364 of the Code of criminal procedure 1898 have been practicing in the criminal trial systems in Bangladesh. Again section 105 of the Evidence Act-1872 state that it is incumbent on the accused to prove the existence of circumstances which bring the offence charged within any exceptionorprovisionintheduepenalcodeandthecourtshallpresumeintheabsenceofsuchcircumstances

.for example, once the prosecution proves that A caused grievous hurt to B , if it is A's contention that he did it in exercise of his right of private or self-defense as mention in sections 95 to 106 of the Penal code-1860. It is for A to prove the circumstance of privatedefense.

This theory of presumption of innocent does not compel a court to believe that the accused is innocent as he might come under the protection of some of the exceptions. In such circumstances, if the defense or accused fail to prove the exceptional circumstances then the accused will be convicted. It may be noted that under the penal code -1860 as practicing in Bangladesh there are also certain other offences relating to Trade Marks, or Property Marks, and Currency and Notes etc. where the burden of proof of innocent is shifted on the accused.

\subsection{Benefit of doubttheory}

This is a very reasonable theory for this research. We now that there is a very fundamental distinction between the civil and criminal trial system as existing in Bangladesh. In the criminal trial system the burden of proving any case is fully dependent on the shoulder of the complainant and the same complainant must have to prove the case beyond reasonable doubt unless the accused shall discharged or acquitted from the charge brought against him. So if there is any doubt in the any of the stages of the criminal trial then the absolute benefit shall go in favor of the accused. So the reasonability lies as the investigation officers have the absolute chance to manipulate the investigation reports upon which the judicial officers have to decide thecase. 


\subsection{Burden of prooftheory}

The term 'burden of proof' is also known as 'onus of proof or onus provandi'. This term refers to the legal obligation on a party to satisfy the court to a specified standard of proof that certain facts are true or false (Halim, M.A 2008, p.61). Burden of proof is the obligation of a party on one side ofa dispute or issue to provide sufficient evidence in support of their allegation (Hasan, S.M. 2010.P 214).In criminal case, the burden of proving the guilty of the accused beyond reasonable doubt is on the prosecution and remains there throughout the trail. This onus never changes. The whole of the facts, however numerous and complicated which go to make the accused guilty must be proved by the prosecution (Hasan, S.M.2010.p.215)..

Their lordship JusticeAbdurRahmanChowdhury observed in Abu NasirBhuiya vs. State casethat-

"It is well settled rule that the burden of proof lies on the prosecution to prove the guilty of the accused beyond reasonable doubt and the general burden on the prosecution never shifts. But under section 105 of the evidence Act the burden of proving the existence of circumstances bringing the case within the exception of the section 84 of the penal code lies on the accused.

\section{3 .a. Shifting of Burden of Proof}

This burden of proof may be shifted from one party to other but in very special and exceptional circumstances. The basis of this exception is the section-105 of the Evidence Act-1872.

According to this section-

When a person is accused of any offence, the burden of proving the existence of circumstance bringing the case within any of the general exceptions in the penal code, or within any special exception or provision contained in any other part of the same code,or in any law defining the offence, is upon his and the court shall presume the absence of such circumstances"

Their lordship in this regard observed in 'Safia Begum vs. Malkani' case that-Burden of proof may shift from party to party. The party asserting affirmatively is not always under the obligation to prove it. Where a rebuttable presumption exists in favor of a party asserting affirmatively the onus lies on the other side to rebut the same"

That means if the accused person affirm or acknowledge that yes he occurred the alleged occurrence but at the time of alleged occurrence he was unsoundness of mind. In this circumstances the informant side's liability is completed but it is the accused party who must have to prove the exceptional circumstances that he was ill or unsoundness of mind, if he can, then he will be treated under section 76 to 95 of the Penal Code, 1860 under general exceptions but if not, he will have to suffer for the occurrence as a guilty.

\section{Theories from Constitutional and AdministrativePerspectives}

\subsection{Theory of Separation ofPowers}

Separation of powers i.e. the executive, the legislature and the judiciary being separated, is a great ally of liberty. According to Montesquieu-"power should be a check on power". (Ahmed, Z, 2015.p.239). According to Lord Acton-he observed that -

"Power corrupts people and absolute power corrupts absolutely, then a good man can be turn into a bad man and a bad man can be turned into a worst one"

Article -22 of the Constitution of Bangladesh is the basic foundation of the theory. According to the

article- "The state shall ensure the separation of judiciary from its executive organ of the state"

In Bangladesh the judiciary was separated from its executive organ of the state in $1^{\text {st }}$ November 2007 by the army backed caretaker government headed by the Dr. FakarUddin in complying the directions and suggestion given by the historic case named MasderHossain case-1999 which was pronounced by the Justice Mostafa Kamal in 1999. But in the nominal sense or in the dependent sense Bangladesh is enjoying the output of the theory. The absolute meaning of the theory is that the three organs of the government namely-the Executive, the legislature and the Judiciary will be free and independent from any types of interference.'Power has an inner trend for misuse and power should act as a check to power. The three branches of government i.e. the Executive, The Legislature and the Judiciary are to be separated although Dr. Garner's Critical view is that -"absolute separation is neither possible nor desirable" (Ahmed, Z, 2015.p.239). Hence the theory of checks and balance is a must to ensure the proper application of the theory.

\subsection{Theory of JudicialReview}

Judicial review means that jurisdiction of the court by which the court declares any law made by the legislative inconsistent with the constitution or with the provision of the fundamental rights and unconstitutional and void (Halim, M.A. 2009.p.62). Judicial review is the ultimate power to the court to declare unconstitutional and hence unenforceable-

i. Anylaw;

ii. Any official action based upon a law;

iii. Any other action by a public official that it deems to be in conflict with the constitution (Abraham,H.). 
It is said that the theory of judicial review took its birth in the year of 1803 by the historic observation of their lordship Chief Justice Marshall in Marburry vs. Madison case that -

"it is emphatically the province and duty of the judicial department to say what the law is .......if two laws conflict each other, the court....... must decide on the operation of each.........if, then, the courts are to regard the constitution and the constitution is superior to an ordinary Act of Legislation, the constitution and not such ordinary Act must govern the case to which they both apply. To decide otherwise would be subversive to the very foundation of all written constitution........all laws repugnant to the constitution are void and courts as well as other departments are bound by that instrument(Constitution).

The doctrine of the Judicial Review may, for the convenience of the researchers to do the constitutional and administrative research and study, be used in two senses: Namely;

a. Theory of Judicial Review in the sense of ConstitutionalSupremacy;

b. Theory of Judicial Review in the sense of ParliamentarySovereignty;

c. Judicial Review under the Theory of ConstitutionalSupremacy.

Theory of judicial review in the sense of constitutional supremacy refers to the powers of the judiciary to examine the constitutionality of laws made by the legislatures .this is the primary and strict meaning of judicial review. But from the broader and liberal point of view the theory includes the following things:

a. Judicial review of laws made bylegislatures;

b. Judicial enforcement of fundamental rights enumerated in theconstitution;

c. Judicial review of administrative actions under the provisions of theconstitution;

d. Judicial review of administrative actions under statutorylaw;

e. Judicial review of delegated law (Halim, M.A.2009.p.62-63).

In a governmental system with constitutional supremacy the constitution itself creates a body empowering it to decide whether or not particular legislation contravenes the constitution and it is natural to commit this function to the judiciary and the fact is that in most cases the Apex court that's the Supreme Court exercise this power of judicial review. But this is not the case in everywhere. Sometimes provisions for separate constitutional court are maintained in the constitution. For example, the Federal constitutional court of Germany which is not a necessary part of ordinary court is invested with the power of judicial review (Article -93 of the basic law for the Federal Republic of Germany). The French system provides a peculiar body for exercising judicial review. The French Constitution is a written one with constitutional supremacy but the supreme court of French has i.e. La Cour de Cassatio has no power of Judicial Review. The constitution provide a constitutional council (Article -56 of the French Constitution) consisting of nine members and this council has the power to test the constitutionality of law. Before passing any organic law (ordinary law), the council must examine them to ensure that they are not conflicting with the constitution (Article -61 of the French Constitution). If the council decare the law unconstitutional, it cannot be promulgated or come into force (Article-62 of the French Constitution).there is no appeal system against the decision of the council which is binding on all public, administrative and judicial authorities.

\subsubsection{Judicial Review in the sense of ParliamentarySovereignty:}

Where there is parliamentary sovereignty, the constitution is unwritten and there is no distinction between fundamental law and the ordinary law. So the court cannot question the constitutionality of any law passed by the parliament (Halim, M.A. 2009.p.64-65). Because there is nothing as a touch stone to test the constitutionality of laws on one hand and on other hand the doctrine of parliamentary sovereignty does not allow anybody to test the legality of law passed by the parliament. In such a system, therefore, there is no judicial review in strict sense. Under this system, there is judicial review in the following two inferior senses:

a. Judicial review of administrative action under statutory law;

b. Judicial review of delegated law and nothing else (Halim, M.A.2009.p.65)

\section{Theory of Rule of Law}

This is another important theory from the constitutional aspect and also functioning as the basis of law in Bangladesh. One of the basic principles of the English Constitution is the rule of law and this theory is accepted both in the constitution of USA and Bangladesh (Ahmed, Z. 2015). Nowadays, this theory of rule of law is one of the most discussed subjects of developing countries like Bangladesh as the developed countries and the donor agencies always instruct the developing countries for sustainable development and good governance. Actually sustainable development and good governance mostly depends on the proper application of rule oflaw.

The term 'Rule of law 'is derived from the French phrase 'La Principle de Legality' (the principle of legality) which refers to a government based on principles of law and not of men and in this sense the concept of 'principle of legality' was opposed to arbitrary powers (Massey, I.P.2001.p.21)The main foundation of the theory is the article -27 of the constitution of Bangladesh. According to this article -"Everyone is equal before 
law and is entitle to get the equal protection of law". This is the main norms of the theory of the rule of law. If one of the prime objectives of law is to maintain law and order in society that's the rule of law, then we can say that there is not rule of law in Bangladesh today as not only the laws in here follows a course of selective and discretionary applicationbut also the institutional and procedural requirements for ensuring rule of law are not effective in this country (Ahmed, Z, 2015.p.469).

Professor Wade gave three ideas about the rule of law; namely

a. It express a preference for law and order within a community rather thananarchy;

b. It express a legal doctrine of fundamental importance, that means the government must be conducted according to law and in any dispute or case what the law requires ,must be declared by the judicial officers accordingly;

c. It refers to a body of political opinion about what the declared rules of law should provide in matters both of substantive and procedure.

Professor A.V. Dicey's Theory of Rule of Law:

We know that Edward coke is said to be the originator of the concept of rule of law but it was the Professor

A.V. Dicey who is very responsible for the development of the theory of rule of law through the writing of a classic book named as 'The Law of Constitution' published in 1885.

According to Dicey, the rule of law is one of the fundamental principles of the English constitution and he give three meaning of the concept of rule of law; namely-

a. Absence of Arbitrary power or the Supremacy oflaw

b. Equality Beforelaw

c. Constitution is the result of the ordinary law of theland.

d. Theory of Necessity (Martiallaw)

In the constitutional law martial law gets its justification in the common law theory of necessity for its promulgation and continuance and all steps taken in exercise of the power $\mathrm{f}$ martial law must be justified by requirements of necessity alone; what is the necessity? That's answer must the necessity of the restoration of the law and order situation of the country (Halim, M. A. 2009. P.423). Thus martial law can be declared as a last resort in times of grave emergency when society is disordered by civil war, insurrection or invasion by any foreign enemy, for speedy restoration of peace and tranquility, public order and safety in which the civil authority may function.

Lord Brougham advocated in favor of this theory. He opines that-"on the pressure of great emergency, such as invasion or rebellion, when there is no time for the slow and cumbrous proceedings of the civil law, a proclamation may justifiable issue for excluding the ordinary tribunals and directing that offence should be tried by military court; such proceeding might be justified by necessity................it is created by necessity and the necessity must limit itscontinuance.

Likewise Justice HamidurRahman observes in the AsmaJilani vs. Government of Punjab and othersthat:-“ Martial law is a machinery for the enforcement of internal order .......is normally brought in by a proclamation issued under the authority of the civil government and it can replace the civil government only where a situation has arisen in which it has become impossible for the civil courts and other civil authorities to function.it is an equally established principle that where the civil courts are sitting and civil authorities are functioning ,the establishment of martial law cannot be justified"

\section{Modern Theories for Maritime Affairs under UnitedNation}

UNCLOS-iii that's the United Nation Convention on the Law of the Sea, 1982 is one of the most important documents regarding the maritime affair which was finally come into force in 1994. This convention has been discharging its functions by delivering the judgments relating to the disputes of maritime boundary delimitation by its two legal institutions namely-ITLOS that means International Tribunal for the Law of The Sea and the Arbitration Court. These two legal institutions recently declared few judgments by following two theories which are discussed below:

\subsection{Theory of Equity}

This theory is based on equity and good conscience. According to this theory the court not only consider the physical or hydro-graphic or geological scenario but also consider the Socio-Economic related issues i.e. National income, national GDP ,Population etc. and its effect upon both the parties of a proceeding. The application of this theory was very effective in recently pronounced two judgments one between Bangladesh vs. Myanmar and other was between Bangladesh vs. India. The cases the ITLOS and the Arbitration Court directly apply this theory of equity in Bangladesh'sfavor. 


\subsection{Theory of Equidistance}

This theory is the exact contrary with the theory of Equity. That means no consideration on sympathetically or humanitarian ground. For example- one deceased left two brothers with a pond of 4 gondas (8 Decimals) of land then divide it exactly by 2 gondas ( 4 decimals) for each without considering whether one brother is deaf or damp or not. In the judgment of the Bangladesh from the ITLOS and the Arbitration Court both India and Myanmar strongly demanded to decide the matter on the theory of Equidistance but the learned international legal institutes did not pay head on their demand rather pronounce the judgment on the basis of Equitabletheory.

\section{Theories ofPunishments}

Although traditionally the theories of punishment are considered separately but in practice it is not easy to drawn such distinction (Ahmed, Z. 2015, p.264). The main objective of punishment is to prevent offences and to reforms the Criminals. In complying with the objective of punishment, there are the five different theories of punishments (Kabir, L. 1970 .p.54); namely:-

\subsection{Deterrenttheory}

Once a judge when delivering his judgment said that,-“I don't punish you for stealing the sheep but so that the sheep may not be stolen for the future time" (Mahajan .V.D.2003.p.137). 'Deter' means to abstain from doing an act. The aim of this theory is to deter (prevent) crime (Ahmed, Z. 2015, p.264). The main object of criminal justice is to award punishment and according to this theory, is to deter people from committing crime (Kabir, L. 1970 .p.54). It serves a warning to the offenders not to repeat the crime in the future and also to other evil-minded person in the society.

The founder of this theory is the Justice Bentham who observes that this theory was based on a hedonistic conception of man and that man as such would be deterred from crime if punishment was applied swiftly, certainly, and severely (Ahmed, Z. 2015, p.265).The deterrent theory was the basis of punishment in England in medieval times and continued to be so till the beginning of the $19^{\text {th }}$ century the result was that severe and inhuman punishments were inflicted even for the minor offences in England i.e. in the time of Queen Elizabeth, the punishment for pick- pocketing was death but in spite of that, pick-picketers were seen busy in their work among the crowds.

\subsection{Preventivetheory}

The preventive theory is founded on the idea of preventing repetition of crime by disabling the offender through measures such as imprisonment, forfeiture, death, punishments and suspension of license etc(Ahmed, Z. 2015, and p.266). This theory was supported by the sagacious law reformers because of its humanizing influence on the penal law and according to their views; it is the certainty of law and its severity which has a real effect on offenders. The modern development of the institution of jail or prison is essentially an outcome of the preventive theory of crime (Ahmed, Z. 2015,p.266).

According to Prof. Paton -'The preventive theory concentrates on the prisoners but seeks to prevent him from offending again in the future".

\section{2. a. Criticisms of this theory:}

This theory has been criticized on the following points:

a. This form of punishment also fails to achieve the desired end as the persons who visit the jail once are habituated to it (Kabir, L. 1970.p.54).

b. It tends to over simply the motives of crime and the motives of crimes are not alwayseconomic;

c. Even in cases of offences actuated by economic motives the economic position of the poor offenders may be such that compensation may not beavailable;

d. If the offender is a rich person the payment of any amount may be no punishment for him etc (Ahmed, Z. 2015,p.266).

\subsection{Retributivetheory}

The word 'Retributive' means to give in return. According to this theory, the offender should be made suffer in proposition to the injury caused to the victims, i.e. a tooth for a tooth, an eye for an eye (Kabir, L. 1970 .p.54).Kant as one of the founder of this theory argues (Ahmed, Z. 2015, p.266) that-"judicial punishment can never be used merely as a means to promote some other good for the criminal himself or civil society, but inserted it must in all cases be imposed on him only on the ground that he has committed a crime"

In the Muslim criminal law, these types of punishment are called the 'QISIS'. Majority of jurists, criminologists, penologists, and sociologists, do not support this theory. 


\subsection{Reformativetheory}

The object of punishment must not to be wreck and vengeance but to reform the criminals so as to prevent him from committing further crime. Crime like other diseases should be properly diagnosed and treated scientifically (Kabir, L. 1970 .p.54).Crime is a malady and the aim of every punishment should be the reformation of the offender by prescribing proper treatment. According to this theory -Crime is like a disease and the theory maintains,-"you cannot cure by killing".

\subsection{Compensatory theory}

The concept of this theory is not only punishing the offenders but also to give the financial remedy to the victim so that $\mathrm{s} / \mathrm{he}$ could recover at the best. Financial burden may also cause for the offender to get back from this wrong way. Here the example of the section -57 of the ICT (Amended) Act, 2009 where the financial burden for this offence may be one corer taka.

\section{CRITICISMS OF LAW}

The main criticism of law is that law is not until the ends of time remain constructive in nature as its consequence for a while brings unenthusiastic productivity. If we criticize law from the affirmative aspect, then can say that we the people or citizens are for the most part in charge for the miscarriage of justice by using the law. What input you submit into the computer, the same shall delivery the consequence of the submitted input as output and for the positive or criticized output the operator of the computer is mainly liable. Hence whatever the laws are there in the country, all are depend on the use and misuse of the same. The Special Powers Act, 1974 is the glittering example of this stage.

\section{CONCLUSION}

Law and legal system of a country is generally natural in nature. It means that law always wants to follow its own way which is very liberal and general for the mass people. But it the very stakeholders or law makers or the agencies related with the law enforcement procedure of the country that are habituated to dominate over the same. This is the way as encouraging the miscarriage of justice. The policy makers should deeply consider the law from its theoretical basis so that the root and original meaning of the law can be understood and ensure justiceaccordingly.

\section{REFERENCES}

[1] Abu NasirBhuiya vs. State (30 DLR 275).AsmaJilani vs. Government of Punjab and others (PLD 1972 132).

[2] Abraham, H. J, the Judiciary: the Supreme Court in the Governmental process, Allyn and Bacon, 5th Edition, London,p.175.

[3] Ahmed, Z, (2015), The Principles of Political Theory, Shams Publication,firstedition,Bangladesh, pp457460

[4] Ahamuduzzaman, (2012), The Legal History and legal system of Bangladesh, Shams Publications, Third Edition,November,

[5] Bangladesh vs. Myanmar, (2012) BLT publication. This judgment was pronounced by the ITLOS on $14^{\text {th }}$ March.

[6] Bangladesh vs. India (2014).This judgment was pronounced by the Arbitration Court in $8^{\text {th }}$ June.

[7] Faruque, G. O.(2005), Method of Judicial Control of Administrative Action In Bangladesh-Principle and Practice, New Warsi Book Corporation, First Edition, August,Dhaka

[8] Halim, M. A. (2014), The Legal System of Bangladesh: A comparative study of problems and procedure in Legal Institutions in Bangladesh. CCB Foundation in Bangladesh, EighthEdition.

[9] Halim, M. A. (2009), Constitution, Constitutional Law and Politics: Bangladesh Perspectives, CCB Foundation, $5^{\text {th }}$ Edition, Dhaka, Bangladesh.

[10] Halim, M. A. (2012), Amendments of the Constitution of Bangladesh: Legislative versus Judicial, CCB Foundation, $1^{\text {st }}$ Edition, Dhaka, Bangladesh.

[11] Halim, A., \&Siddiki, N.E. (2008), The Legal System of Bangladesh after Separation, Published by University Publication in Bangladesh, First Published inFebruary.

[12] Halim, M. A.(2008), The law of Evidence-theory and practice, Published by CCB Foundation: Lighting the Dark, First Edition, July, Dhaka.

[13] Khan, H. (1993).Jurisprudence \& Comparative Legal Theory, AnupamGyanBhandar, FirstEdition.

[14] Hasan, S. M. M.(2010),Be Advocate, Shams Publications, First Edition in August.Dhaka.

[15] Hossen, A.P.(1998). Jurisprudence, Mohanagar Law BookCentre,

[16] Kabir, L. (1970),Lectures on the Pakistan Penal Code (with leading cases), Published by Law House, Dhaka, 
[17] Khan, M. A. A. (2010), Principles of Judicial Methodology and Propriety, Kamrul Book House in Bangladesh, $1^{\text {st }}$ published inJanuary.

[18] Mahajan, V.D. (2003), Jurisprudence \& Legal Theory, Eastern Book Company, Fifth Edition, Reprinted.

[19] Marbury vs. Medison case.5U.S.137(1803).

[20] Masder, H. Case. (1999),(Famously known as Separation of judiciary case in Bangladesh) 20BLD 2000(AD) 104, 52DLR2000(AD)82.

[21] Massey, I.P. (2001), Conceptual Objections against the Growth of Administrative law, Administrative Law, $5^{\text {th }}$ Edition, Eastern Book Company, Lalbagh, Lucknowk,India.

[22] Talukder, S.M. H. (1994), Independence of Judiciaryin Bangladesh: Law and Practice,AnindyaPrakasani, Dhaka, Bangladesh, First Printed,January.

[23] Takwani, C.K. (2003), Lectures on Administrative Law, Eastern Book Company, Lucknow,India.

[24] The Constitution of the People's Republic ofBangladesh-1972.

[25] The Code of Criminal Procedure-1898.

[26] The Code of CivilProcedue-1908.

[27] The Law of Evidence -1872.The PenalCode-1860.

[28] Safia Begum vs. Malkani( PLD 1965Lah.575)

[29] State vs. Balahari Das Sutradhar( 13 DLR289) 